\begin{tabular}{|l|l|l|}
\hline \multicolumn{2}{|c|}{ PublisherInfo } \\
\hline \hline PublisherName & $:$ & BioMed Central \\
\hline \hline PublisherLocation & $:$ & London \\
\hline \hline PublisherImprintName & $:$ & BioMed Central \\
\hline \hline
\end{tabular}

\title{
Adenovirus-delivered TIMP-1 in the rheumatoid arthritis mouse model
}

\begin{tabular}{||l|l|l||}
\hline \multicolumn{2}{|c|}{ ArticleInfo } \\
\hline \hline ArticleID & $:$ & 275 \\
\hline \hline ArticleDOI & $:$ & $10.1186 /$ ar-2002-75850 \\
\hline \hline ArticleCitationID & $:$ & 75850 \\
\hline \hline ArticleSequenceNumber & $:$ & 28 \\
\hline \hline ArticleCategory & $:$ & Paper Report \\
\hline \hline ArticleFirstPage & $:$ & 1 \\
\hline \hline ArticleLastPage & $:$ & 3 \\
\hline \hline & & RegistrationDate $: 2002-2-20$ \\
ArticleHistory & $:$ & Received \\
& Accepted 2002-2-20 & $: 2002-3-27$ \\
& & OnlineDate $\quad 2002-3-27$ \\
\hline \hline ArticleCopyright & $:$ & Biomed Central Ltd2002 \\
\hline \hline
\end{tabular}




\begin{tabular}{|l|l|l||}
\hline \hline ArticleGrants & $:$ & \\
\hline \hline ArticleContext & $:$ & 130754411 \\
\hline
\end{tabular}

Masahide Kashiwagi, Aff1

Aff1 Kennedy Institute of Rheumatology, London, UK

\section{Keywords}

collagen induced arthritis, TIMP-1

\section{Context}

Matrix metalloproteinases (MMPs) have been implicated to play an important role in degradation of cartilage matrix, and elevated levels of MMPs have been detected in synovial tissue, synovial fluid and serum from rheumatoid arthritis (RA) patients. The mechanisms of cartilage destruction in RA, however, have not been clearly elucidated. Overexpression of tissue inhibitor of MMPs type 1 (TIMP-1) in the collagen-induced arthritis (CIA) mouse and in the tumor necrosis factor (TNF)-a transgenic mouse has very different effects. In the case of CIA mice, TIMP-1 cannot prevent the destruction of cartilage matrix and even increases the severity of inflammation in arthritic joints (see Additional information). This study investigated the effects of TIMP-1 overexpression in TNF-a transgenic mice.

\section{Significant findings}

Adenovirus based human TIMP-1 (hTIMP-1) gene delivery led to expression mainly in the thymus, spleen and liver in TNF-a transgenic mice. The serum levels of hTIMP-1 were 1300 ? $435 \mathrm{pg} / \mathrm{ml}$ (Day 3). TIMP-1 treatment did not modify the serum levels of TNF-a, soluble TNF receptor 1 (TNFRI) or IL-6 compared to controls. Overexpression of hTIMP-1 in the TNF-a transgenic mice showed significant improvement of arthritic features (paw swelling, grip strength and ankle thickness) compared to controls. There was also remarkable reduction in severity of the disease as demonstrated by radiological and histological analysis of joints. Immunohistochemistry with anti-TIMP-1 and MMP-3 antibodies showed colocalization of the two molecules, implying that overexpressed hTIMP-1 targeted endogenous MMP-3, predominantly localized in arthritic joints. In addition, TIMP-1 treatment reduced the levels of serum autoantibodies against heterogeneous nuclear ribonuclear protein A2 (RA33), suggesting suppression of disease progression. 


\section{Comments}

Adenovirus-delivered hTIMP-1 gene has been evaluated in both CIA and TNF transgenic mice, and quite distinct effects have been observed. However, significantly different levels of hTIMP-1 have been detected in the serum (approximately $3 ? \mathrm{~g} / \mathrm{ml}$ in CIA mice versus $1.3 \mathrm{ng} / \mathrm{ml}$ in TNF-a transgenic mice at Day 3). These observations imply that expressed hTIMP-1 was free from its main targets (mainly MMPs) in CIA mice, and failed to inhibit them, resulting in an arthritic phenotype. In the TNF-a transgenic mice, hTIMP-1 could bind MMPs effectively. These contrary effects of TIMP-1 in the two different RA models may also be explained by differences in the molecular mechanisms of the disease process in the two mouse models.

\section{Methods}

Induction of CIA, adenoviral vectors, ELISA, immunohistochemistry, analysis of antoantibodies.

\section{Additional information}

Apparailly F, Noel D, Millet V, Baker AH, Lisignoli G, Jacquet C, Kaiser MJ, Sany J, Jorgensen C: Paradoxical effects of tissue inhibitor of metalloproteinases 1 gene transfer in collagen-induced arthritis. Arthritis Rheum, 2001 44: 1444-1454.

\section{References}

1. Schett G, Hayer S, Tohidast-Akrad M, Schmid BJ, Lang S, Turk B, Kainberger F, Haralambous S, Kollias G, Newby AC, Xu Q, Steiner G, Smolen J: Adenovirus-based overexpression of tissue inhibitor of metalloproteinases 1 reduces tissue damage in the joints of tumor necrosis factor alpha transgenic mice. Arthritis Rheum. 2001, 44: 2888-2898.

This PDF file was created after publication. 